\title{
The biology and functional morphology of Nucula pusilla (Bivalvia: Protobranchia: Nuculidae) from Western Australia, Australia: primitive or miniature simplicity?
}

\author{
Brian Morton
}

Department of Zoology, The Natural History Museum, Cromwell Road, London SW7 5BD, United
Kingdom. E-mail: prof_bmorton@hotmail.co.uk

\begin{abstract}
The southern Australian nuculid Nucula pusilla is $<3 \mathrm{~mm}$ in shell length, making it one of the smallest known protobranchs and one of the smallest bivalves. It lives in clean, well-aerated, coarse, offshore marine sands in the southern half of the Australian continent. The bivalve lies in the sand with the pointed anterior end of the shell directed upwards at an angle of $\sim 45^{\circ}$ to the sediment surface and inhales water into the mantle cavity from this direction. The more rounded posterior shell margin sits within the sediment. The posterior exhalant current, created by the posterior, largely respiratory ctenidia assist in the removal, along with ciliary currents on the mantle surface and visceral mass, of unwanted particles. Nucula pusilla possesses a pair of large, closed statocysts with numerous statoconia, situated above the pedal ganglia and these are likely to be responsible for the bivalve's orientation. There is also a minute Stempel's organ located on the outer face of the anterior adductor muscle. Feeding is largely by means of palp proboscides that collect subsurface material and transport it along anterior ciliated grooves where it reaches and is sorted by the labial palps where some particles are accepted and others are rejected. The intestine is coiled complexly in the visceral mass but the style sac is much simplified in comparison with $N$. sulcata.
\end{abstract}

The mantle margin of Nucula pusilla is simplified, with the periostracal groove, in contrast to $N$. sulcata, extending almost to the pallial line. Other features of $N$. pusilla anatomy are described and although this species is clearly closely similar in morphological terms to other widely accepted 'primitive' nuculids, it appears that miniaturisation has resulted in some anatomical simplification. As with all species, form and function result ultimately from ancestry and the evolutionary path arising from natural selection. Aspects of the morphology of N. pusilla, such as the mantle margin, the simply structured style sac, the uniquely protobranch Stempel's organ, and the mantle cavity brooding of lecithotrophic larvae, are indicative of a 'primitive', perhaps ancestral, nuculid condition. Other aspects of the overall body plan, such as the loss of the anterior pedal retractor muscles, suggest simplification resulting from miniaturisation. It is suggested that through paedomorphosis, miniaturisation of a nuculid ancestor could be the means by which the 'higher' lamellibranch bivalves have so successfully adopted a ctenidial and suspension feeding lifestyle and been released from the constraints that deposit feeding imposes. These bivalves have subsequently diverged into a complex array of species inhabiting virtually every aquatic habitat on Earth.

KEYWORDS: musculature, mantle margin, intestine, Stempel's organ, reproduction, larval brooding, paedomorphosis, neoteny

\section{INTRODUCTION}

Yonge (1939) undertook the first comprehensive, now classical, work on the functional morphology of representatives of the various protobranch families, examining Nucula hanleyi Winkworth, 1931, N. nucleus (Linnaeus, 1758) and N. turgida Leckenby and Marshall, 1875 as representatives of the Nuculidae J.E. Gray, 1824. Yonge was describing the generally well known larger ( 13 mm shell length) British species of Nucula, the similar shells of which were described and compared by Allen (1954), and subsequently by Tebble (1966). So similar are nuculid shells that Allen (1952) attempted to distinguish between the structure of the faecal pellets of two putative species of Nucula, N. turgida and N. moorei Winckworth, 1931 and concluded by synonymising the latter with the former. Such uniformity led Sanders and Allen (1973 p. 239) to define the Nuculidae as a 'sharply circumscribed and well-defined morphological group'.

Yonge (1939) pointed out that the anatomy of Nucula is the best known amongst all protobranchs. However, 
there has never been (i) any examination of the anatomy of an Australian species nor (ii) of such a minute taxa as $N$. pusilla Angas, 1877, the object of this study. This is surprising considering Lamprell and Healy (1998) redescribed 21 species of nuculids belonging to three genera (Nucula Gray, 1824, Rumptunucula Bergmans, 1978 and Leionucula Quenstedt, 1930) from Australian waters, but is possibly less so when the small size of $N$. pusilla is considered. The research reported here thus complements that of Yonge (1939) and draws on the anatomical researches of earlier workers such as Drew (1899; 1901), Pelseneer (1911) and Heath (1937) as well as more contemporary authors who have researched the finer details of different nuculid species. These latter authors will be identified in the relevant sections of this text. This study also seeks to provide better illustrations of a nuculid taxon, congeners of which have not previously been illustrated as living entities but as either dried or preserved specimens, for example Hampson (1971), Allen (1978), and Yonge (1939).

Finally, because Nucula pusilla is so small, this study may give some insights into what the primitive, ancestral bivalve was like as they were also tiny (Runnegar 1978). Yonge (1939) considered the Nuculidae to be the least specialised of the Protobranchia and to be representative of the most primitive living lamellibranch bivalves. Conversely, Graham (1949) studied the stomach of $N$. hanleyi and noted (page 742): 'the structure of the stomach of Nucula does not in some respects suggest primitiveness, but a certain degree of specialisation'. Following a study of $N$. nucleus, Purchon (1956) linked the protobranchs with the anomalodesmatan septibranchs because of stomach simplicity, although such a similarity is derived from the fact that representatives of both ingest large particles of food resulting in a high degree of extracellular digestion. In the case of the latter, this is because of the ingestion of preyed-upon small crustaceans, for example, in species of Cuspidaria (Reid and Reid 1974), not detritus as in protobranchs.

Modern biologists now view animals under a somewhat different light suggesting that in order to survive, all species must be specialised to meet the demands of their ecology in its broadest sense. Hence, although the Nuculidae may in some ways be representative of the primitive, ancestral bivalve form and lifestyle, suggested by Yonge (1939), arguably the greatest 20th century authority on the Bivalvia, the minuteness of $N$. pusilla may illuminate aspects of the ancestral nuculid and/or bivalve condition, as well as the role that minuteness plays in determining the complexity (or not) of functional anatomy. Whether N. pusilla would reveal any insights into how its anatomy reflected either primitive or miniature simplicity became the overall aim of this study.

\section{MATERIALS AND METHODS}

Individuals of Nucula pusilla were obtained by sieving coarse shallow subtidal sands from off Cape Vlamingh,
Rottnest Island, off Perth, Western Australia, during the course of the Fifth International Marine Biological Workshop, convened on Rottnest Island from 1-24 January 1991. The antero-posterior shell lengths of each individual plus empty right valves were measured to the nearest $0.1 \mathrm{~mm}$ using vernier calipers. Subsequently, some of the largest individuals were dissected and the ciliary currents of the mantle cavity elucidated by the application of drops of carmine suspended in seawater. Two other individuals of $\sim 1 \mathrm{~mm}$ and $\sim 2 \mathrm{~mm}$ shell length were fixed in Bouin's fluid and following routine histological procedures, sectioned transversely at $4 \mu \mathrm{m}$, and resulting slides stained in either Ehrlich's haematoxylin and eosin or Masson's trichrome.

For comparison, two individuals of Nucula sulcata (Bronn, 1831) were obtained from the Milport Marine Station courtesy of the then Director J.A. Allen. These were dissected and sectioned using the same procedures as described above for $N$. pusilla.

\section{RESULTS}

\section{TAXONOMY AND FOSSIL HISTORY}

Keen (1969) considered that representatives of the Nuculidae have a fossil history dating from the Ordovician and that Recent species occur almost worldwide. Angas (1877, page 177, plate XXVI, figure 26) described and recorded Nucula pusilla from shellysand from Port Jackson, South Australia. Bergmans (1978) described the taxonomy and distribution of fourteen species of Recent Australian Nucula and selected a lectotype for $N$. pusilla Angas, 1877, which is held in the collections of the Natural History Museum, London (BMNH 1877.5.12.61), and considered $N$. hedleyi Pritchard and Gatliff, 1904, N. micans Angas, 1879 and Pronucula concentrica Cotton, 1930 to be junior synonyms. According to Huber (2010), another synonym is $N$. minuta Tenison-Woods, 1876 but this species is restricted to the Canadian Arctic and is likely to be a valid taxon. The shell of the lectotype of $N$. pusilla is illustrated in Bergmans (1978, figures 2-4).

In the collection of fossil nuculids contained in the Western Australian Museum (WAM), N. pusilla has been obtained from Pliocene, Pleistocene and Recent strata at Jandikot and Redcliffe in Perth and from West Gingin, north of Perth, and Rottnest Island.

\section{BIOLOGY}

Nucula pusilla can be considered to have a southern Australian, cold temperate distribution, and to live in clean, nearshore, oceanic sediments. With a recorded maximum shell length of $2.92 \mathrm{~mm}$ (Bergmans 1978), $\mathrm{N}$. pusilla is a minute occupant of sediments comprising medium to coarse well sorted sands $(0.25-1.00 \mathrm{~mm})$ (Glover and Taylor 1999). Adult N. pusilla individuals are only a little bigger than the largest grains in the sediments in which they live. 


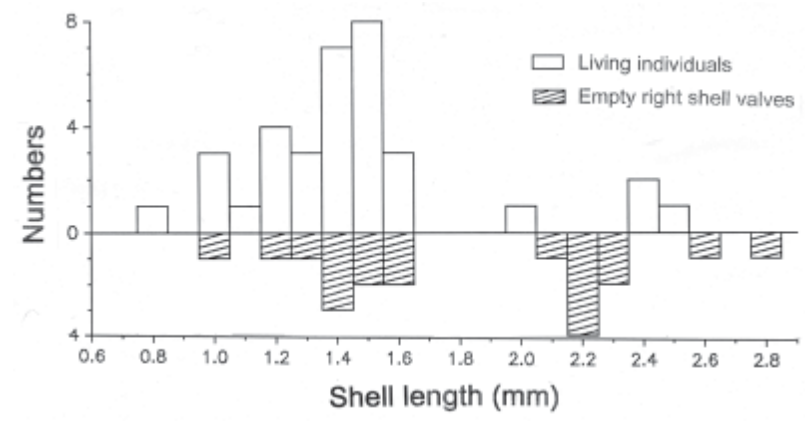

FIGURE 1 Nucula pusilla. Shell length frequency histogram of a sample of (i) living individuals and (ii) empty right shell valves collected from offshore sands at Cape Vlamingh, Rottnest Island, Western Australia.

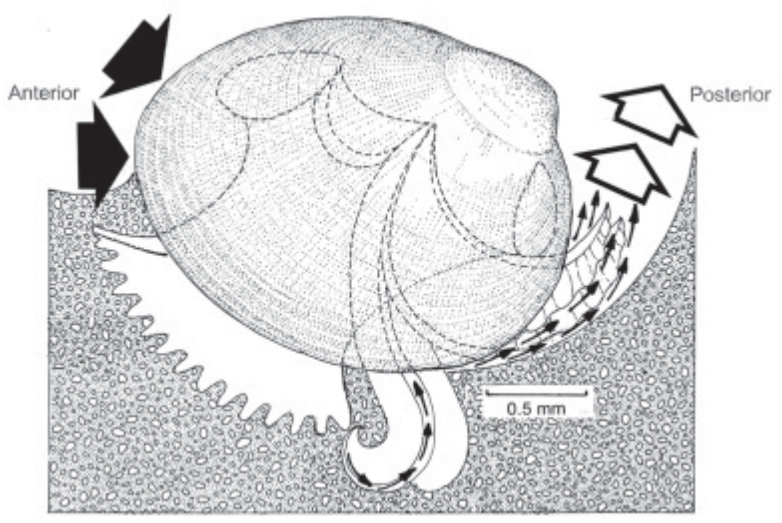

FIGURE 2 Nucula pusilla. An illustration of the living animal buried in a natural position in the sand and showing the anterior inhalant and posterior exhalant streams. Also shown are the tips of the palp proboscides in the sediment and the posterior ends of the ctenidia.

Figure 1 is a shell length frequency histogram of a sample of (i) living individuals and (ii) empty right shell valves of Nucula pusilla collected from offshore sands at Cape Vlamingh, Rottnest Island, Western Australia. It comprises two peaks of living individuals of $\sim 1.4$ $\mathrm{mm}$ and $\sim 2.4 \mathrm{~mm}$ shell length and empty (right) valves of approximately matching sizes $(1.4 \mathrm{~mm}$ and $2.2 \mathrm{~mm}$ shell lengths). The smallest living individual had a shell length of $0.8 \mathrm{~mm}$. I have no data on the population density of N. pusilla at Cape Vlamingh but this may not be significant as the species is particularly susceptible to changes in water quality. Macleod and Forbes (2004) found numbers of $N$. pusilla declined rapidly in the sediments beneath finfish farms in Tasmania subjected to eutrophication from artificial feeds, but recovered once impacts ceased.

In laboratory aquaria with a bed of sand from their natural habitat, living individuals of Nucula pusilla reburied themselves quickly and adopted positions generally similar to that illustrated in Figure 2. In

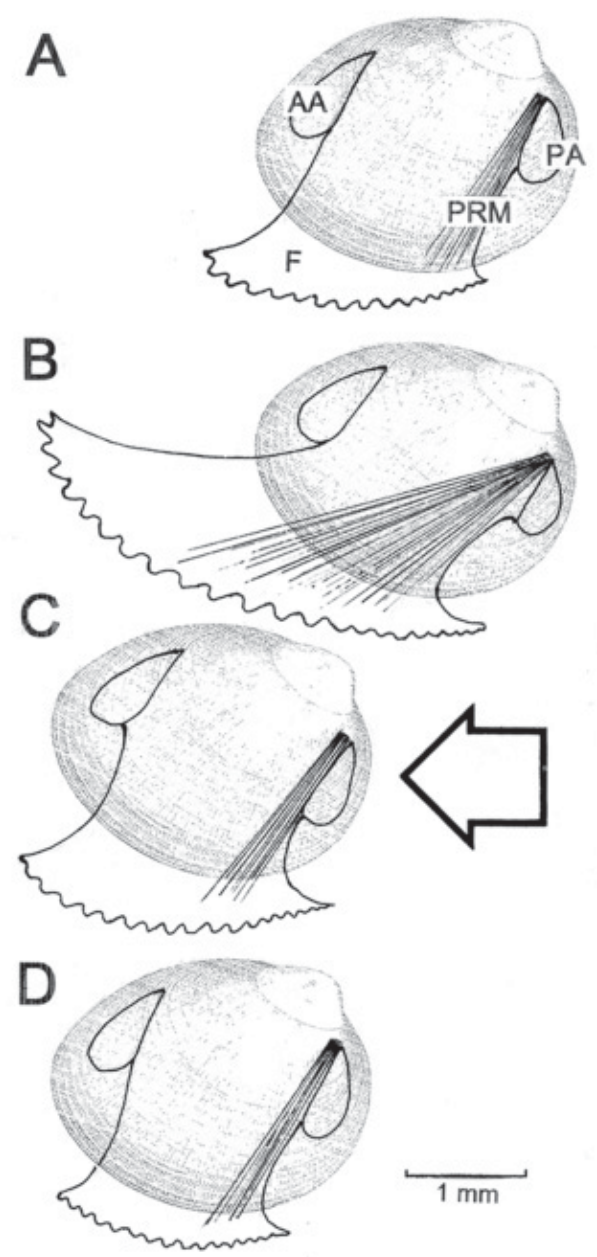

FIGURE 3 Nucula pusilla. The method of locomotion with the foot extended forward and the shell pulled towards it by means of the contraction of the posterior pedal retractor muscle. (For abbreviations see Appendix).

this natural position, they buried themselves with the posterior ends downwards and the pointed anterior ends of their shells oriented somewhat upwards out of the sediment. The application of suspended carmine to living individuals identified an anterior inhalant stream and some of this was eventually passed out of the animal postero-ventrally as a posterior exhalant stream. Also illustrated are the tips of the palp proboscides extended into the sediment and the posterior ends of the ctenidia that extend beyond the posterior margin of the shell valves (Figure 2).

The foot of various species of Nucula has been described as a 'creeping' organ (Forbes and Hanley 1853, Pelseneer 1891, Verrill and Bush 1897, 1898). Yonge (1939) rectified this error and described, but did not illustrate, how locomotion was achieved. The method of locomotion exhibited by $N$. pusilla is illustrated in Figure 3. From a resting position illustrated in Figure 3A, the marginally frilled foot is extended forwards in an anteriorly oblique direction, 
expanded, and flared outwards (Figure 3B). The shell is then pulled forwards by contraction of the paired posterior pedal retractor muscles (Figure 3C). Associated with this action the parted shell valves are brought together by adduction of the adductor muscles and this provides the lift and momentum for the whole animal to be pulled forward. Further foot extensions may occur subsequently, such that an individual may either continue forward motion or return to and adopt a position of repose (Figure 3D). The frilled ploughshare structure of the foot of $N$. pusilla is similar to those of the preserved nuculids illustrated by various authors, for example Pelseneer (1911, plate I, figure 1) and the highly active, and deep burrowing, Solemya parkinsoni Smith, 1874 (Owen 1961, figure 2D) and S. velesiana Iredale, 1931 (Taylor et al. 2008, figure 12A and B).

\section{ANATOMY}

\section{The shell}

The shell of Nucula pusilla is minute, the largest individual here reported having a length of $2.8 \mathrm{~mm}$. Bergmans (1978, table 1) recorded that the holotype of Pronucula concentrica Cotton, 1930 from Gulf St Vincent, which he considered to be a junior synonym of $N$. pusilla, had a shell length of $3.75 \mathrm{~mm}$. All other specimens reported by Bergmans had shell lengths $<2.92 \mathrm{~mm}$. Moore (1977) recorded that the Nuculidae comprise some of the smallest living bivalves and rarely do any species reach a shell length $>50 \mathrm{~mm}$. At 20 $\mathrm{mm}, N$. sulcata is the largest British species, all four other species having maximum shell lengths of $\sim 13 \mathrm{~mm}$ (Tebble 1966).

The aragonitic shells of all nuculids, both Recent and fossil, examined by Taylor et al. (1969, table 1) comprise three layers, an outer layer of composite prisms, and middle and inner layers of lenticular and sheet nacre, respectively. The equivalve shell of $N$. pusilla (Figure 4) is obliquely and triangularly ovate, or wedge-shaped, and distinctly inequilateral, the antero-dorsal margin sloping more gently than the postero-dorsal resulting in truncate anterior and more rounded posterior valve margins. Externally (Figure 4A), the shell is relatively thin, pale greenish-white, finely and commarginally striated externally, and crossed with extremely delicate radiating striae. The ventral margin is smoothly arcuate, and the postero-dorsal umbones swollen with opisthogyrate umbones. Internally (Figure 4B) the shell of $N$. pusilla is nacreous, as in all nuculids, and slightly translucent.

When the shell of Nucula pusilla is angled slightly (Figure 5A) the scars of the anterior (AA) and posterior (PA) adductor muscles can be clearly seen. The scar of the posterior pedal retractor (PPR) is visible beneath the posterior region of the hinge plate, and the extremely thin, obscure and deeply recessed pallial line (PL) is also more obvious. The prodissoconch of $N$. pusilla is large ( 260 $\mu \mathrm{m}$ in length) and corroded (Figure $5 \mathrm{~B})$. Also apparent are tiny larval hinge teeth (LT) (Figure 5B). Another view of the interior of the right shell valve shows the structure of the hinge in greater detail

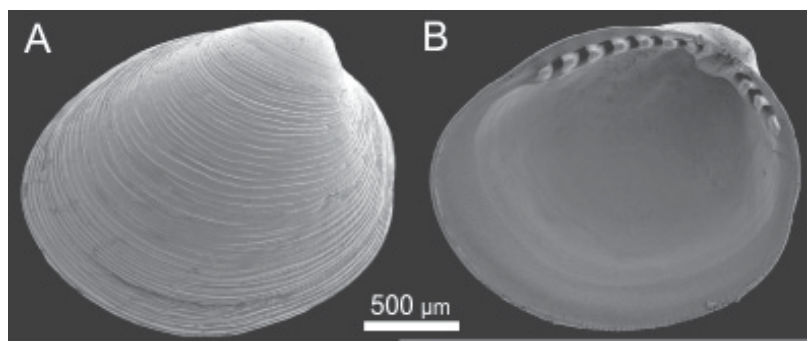

FIGURE 4 Nucula pusilla. The shell. A. Exterior view of the left shell valve. B. Interior view of the right shell valve.

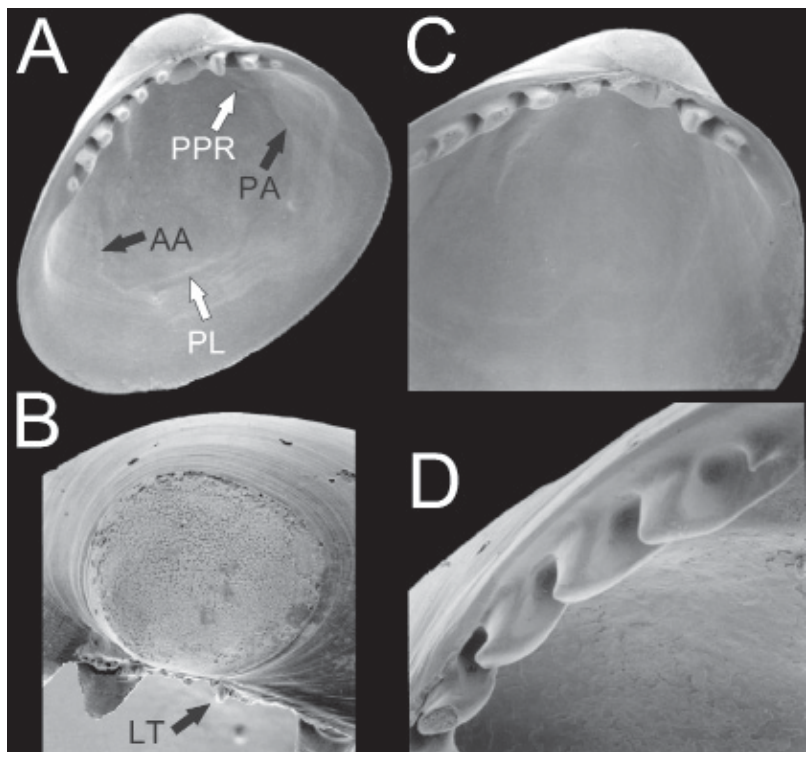

FIGURE 5 Nucula pusilla. A. Angled view of the interior of a $2 \mathrm{~mm}$ long left shell valve with the adductor muscles and pallial line identified. B. Corroded prodissoconch, $\sim 260 \mu \mathrm{m}$ in length also showing the larval teeth. C. Interior view of the left shell valve of an individual of $\sim 1.6$ $\mathrm{mm}$ shell length showing the structure of the hinge in greater detail. D. Detailed, oblique, view of the hinge teeth of the left shell valve. (For abbreviations see Appendix).

(Figure 5C) and the central approximately amphidetic, opisthogyrate ligament with the prodissoconch situated above it, and the taxodont anterior (x6) and posterior (x3) hinge teeth. A more detailed view of the hinge teeth of the right shell valve (Figure 5D) shows that the anterior hinge teeth are pointedly curved towards the anterior, with a socket behind.

The hinge plate is also illustrated in Figure 5C. The triangular ligament of the hinge plate is internal and situated on a resilifer, not a chondrophore, as suggested by Bergmans (1978). In an adult individual $2.5 \mathrm{~mm}$ in shell length, taxodont hinge teeth are present both anteriorly and posteriorly, the maximum numbers being eight and four, respectively, for example in the lectotype (Bergmans 1978, figure 3). The thin pallial line and the scars of the larger posterior and smaller anterior 
adductor muscles are visible, while the scar of the only pedal retractor muscle, the posterior, is hidden under the hinge plate.

\section{The musculature}

The musculature of Nucula pusilla comprises approximately equal anterior and posterior adductor muscles (Figure 3A, AA; PA), although the former is slightly larger than the latter, so the species is approximately isomyarian. There is a large posterior pedal retractor muscle (PRM), but no anterior equivalent. Neither Yonge (1939) nor Hampson (1971) describe any pedal retractor muscles for the nuculids they examined although Mikkelsen and Bieler (2008) illustrate and describe both a large posterior and a smaller anterior pedal retractor for an unidentified, possibly generalised, species of Nucula. Haszprunar (1985, figure 1a) described a similar arrangement of muscles in N. sulcata.

A Stempel's organ is present on the anterior, outer face of the anterior adductor muscle of Nucula pusilla (Figure $6, \mathrm{SO}$ ). It is a minute structure closely adherent to the anterior adductor muscle (AA) and embedded within the united inner folds of the mantle margin (IMF). The organ is $\sim 6 \mu \mathrm{m}$ in diameter and comprises a sphere of nucleolated cells enclosing a hollow central core with a statolith-like structure inside. The mantle margin above the anterior adductor muscle comprises outer (OMF) and middle (MMF) mantle folds with the periostracum (PE) arising between them. The outer mantle fold is here densely occupied by sub-epithelial secretory cells (SC).

\section{Comparison with Nucula sulcata}

The Stempel's organ present in Nucula sulcata has been described in great detail by Haszprunar (1985). As in N. pusilla, the organ in N. sulcata is located on the anterior face of the anterior adductor muscle. It has a form reminiscent of the muscle of $N$. pusilla (Haszprunar 1985, figure 4), but is much more complex and comprises a closed tube that is innervated from the pleural ganglia. The lumen of the organ is filled with a ventral crest that comprises ciliated cells and it is believed that the structure functions as a mechanoreceptor, possibly associated with the coordination of the organs of feeding, the labial palps, palp proboscides, and possibly the ctenidia.

\section{The mantle margin}

The mantle margin of Nucula pusilla is divided throughout its extent, except dorsally beneath the hinge plate and between the adductor muscles. The mantle margin of $N$. pusilla is exceedingly simple (Figure 7) but does comprise the three folds typical of the majority of the bivalves except for some arcoids, e.g. Arca noae (Linnaeus, 1758) (Morton and Peharda 2008). The inner fold (Figure 7, IMF) is small and swollen and contains the pallial nerve (PN). The middle (MMF) and outer mantle folds (OMF) are exceedingly long and receive most of the components of the pallial retractor muscle (PRM), which is also long, reflecting the distance of

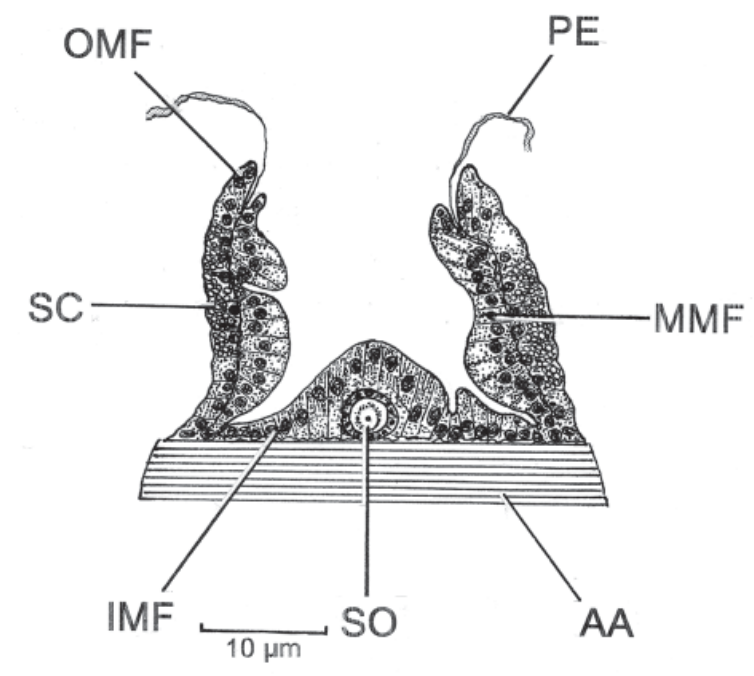

FIGURE 6 Nucula pusilla. Transverse section through Stempel's organ located on the outer face of the anterior adductor muscle. (For abbreviations see Appendix).

the pallial line inwards from each valve margin (Figure 5A, PL). Between these two folds lies the periostracal groove (Figure 7, PEG) which basally secrets the periostracum that stains blue in Masson's trichrome.

\section{Comparison with Nucula sulcata}

The mantle margin of this species of Nucula also comprises the three folds typical of the Bivalvia (Figure 8 ) except that the folds are arranged differently from N. pusilla. The inner mantle fold (IMF) is much larger and the middle (MMF) and outer folds (OMF) are considerably shorter in N. sulcata. As a consequence, although the pedal retractor muscle (PRM) in $N$. sulcata is as long, relative to N. pusilla, the periostracal groove (PEG) is proportionally much shorter (Figure 8). In the two much larger individuals of $N$. sulcata, the periostracum (PE) is seen to comprise two layers, an inner layer that stains blue in Masson's trichrome suggesting a mucoid structure, and a thin outer chitinous layer.

\section{The organs of the mantle cavity}

The organs and ciliary currents of the mantle cavity of Nucula pusilla, seen from the left side, are illustrated in Figure 9. In living individuals (Figure 2), there is a strong anterior inhalant stream and an equally distinct posterior exhalant flow which are presumably almost completely a respiratory flow, as the water passes through and around the paired and curved ctenidia that comprise inner (ID) and outer demibranchs (OD), located in the posterior region of the mantle cavity. The ctenidia, or gills, of an unidentified species of Nucula were studied by Orton (1912) and discussed by Atkins (1937) who also provided an illustration (Atkins 1938, figure 7A) of a transverse section through a gill filament. 


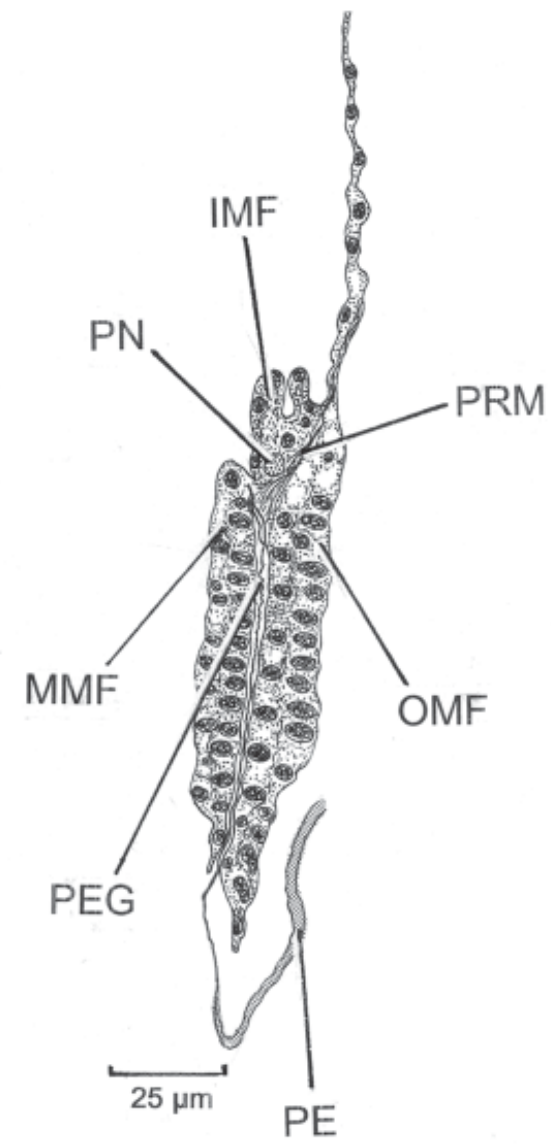

FIGURE 7 Nucula pusilla. Transverse section through the right ventral mantle margin. (For abbreviations see Appendix).

The ctenidia of $N$. pusilla possess few or no filtering or particle collecting facilities and any suspended material retained by these structures is rejected from their surfaces quickly, typically from the ventral extremities of the ctenidial filaments, and from the mantle cavity with the posterior exhalant stream. Yonge (1939, figures 9 and 10) illustrated similar ctenidia in $N$. hanleyi and $N$. turgida. Stasek (1961) showed, as illustrated here for $N$. pusilla, that the nuculid Acila castrensis (Hinds, 1843) possesses an intimate association between the ctenidia and the labial palp lamellae, suggesting that food collection in these species may also comprise an element of suspension feeding.

The feeding structures of Nucula pusilla comprise the paired palp proboscides (Figure 9, LPP, RPP) that are situated in the mantle cavity between the anteriorly situated paired, inner and outer labial palps (ILP, OLP), and the posteriorly located, also paired ctenidia. The palp proboscides are long, truncated, extensible structures that probe into the habitat sediments from between the parted shell valves approximately mid ventrally. On their anterior faces are ciliary channels that collect particles of sediment and pass them upwards towards the labial palps.

The position of the labial palps in the mantle cavity

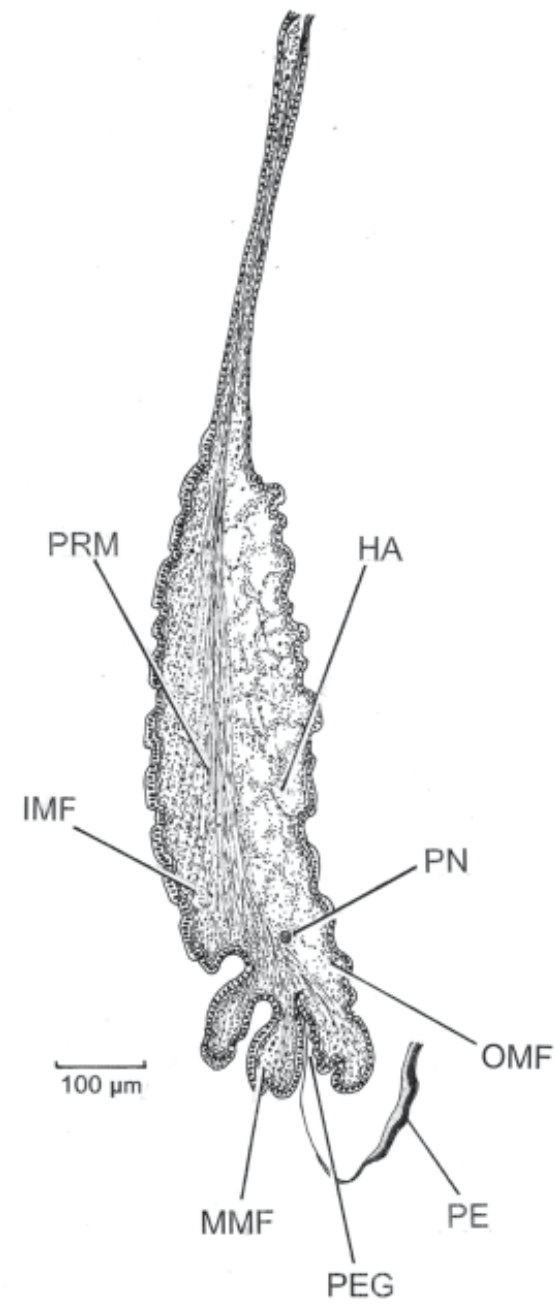

FIGURE 8 Nucula sulcata. Transverse section through the right ventral mantle margin. (For abbreviations see Appendix).

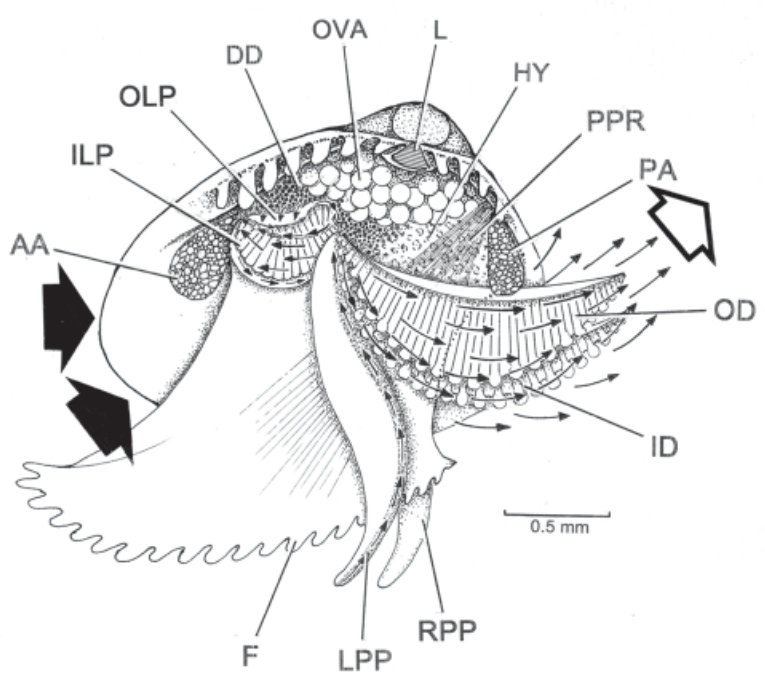

FIGURE 9 Nucula pusilla. Organs and ciliary currents of the mantle cavity as seen from the left side and after removal of the left mantle lobe. (For abbreviations see Appendix). 
of Nucula pusilla is illustrated in Figure 9. Figure 10 is a more detailed representation of the labial palp - palp proboscide junction showing the ciliary currents of the former. In this figure only the left palp proboscides (LPP) and left labial palps (ILP, OLP) are illustrated. On the anterior face of the former is a particle collecting tract (PCT) that passes material collected from the sediment upwards where it finally accumulates in the distal oral groove (DOG), posterior to the labial palps. In this illustration, the outer labial palp (OLP) is lifted to expose the lamellar inner surfaces of both structures and the labial palp pouch (LPO). Between these is the proximal oral groove (POG) that extends from the anterior end of the distal oral grove and terminates at the mouth (not illustrated). In life, when the two palps hang down, collected material passing between them from the distal to the oral grooves would be subjected to ciliary currents on these palp surfaces. The nuculid ctenidial - palp proboscides - labial palp junction was defined by Stasek (1963) as Category I and illustrated for Acila castrensis (figures 1a and b).

In broad terms, material potentially acceptable for ingestion passes over the apices of the palp lamellae towards the proximal oral groove (Figure 10). Conversely, material potentially unacceptable for ingestion, either due to size or unpalatability, is passed into the depths of the grooves between adjacent palp ridges and towards the palp margins where it is transported in an aboral direction back to the palp proboscides and rejected.

Details of the ciliary currents of two ridges that coordinate either the acceptance or rejection processes on the labial palps of Nucula pusilla are illustrated in Figure 11. As described above an orally directed acceptance tract is located on the crests of the palp ridges and transports material towards the proximal oral groove and mouth. In the bases of the grooves between the palp ridges are rejection tracts that transport unwanted particles towards the margins of the palps, where they are then passed aborally and rejected. On the oral and aboral surfaces of the palp ridges are resorting currents that are relatively simple in this 'deposit' feeder, compared to other nuculids and nuculanids, e.g. Acila castrensis and Yoldia ensifera Dall, 1897, respectively, which are able to (reportedly) also function as 'suspension' feeders and are much more complex (Stasek 1961, 1965).

In Nucula pusilla, inwardly and outwardly directed tracts lead towards the tips of the ridges, and downwardly directed tracts towards both the oral and aboral faces of the palp ridges, meaning that the sorting of material for either acceptance or rejection is restricted to the apices of the palp ridges. This may be related to habitat, bearing in mind the coarse well sorted sand habitat of $N$. pusilla, most palp proboscid-collected material will be wholly unsuitable for acceptance and would need to be rejected. In this process, the functions of the mantle and visceral mass complement the ciliary currents of the labial palps.

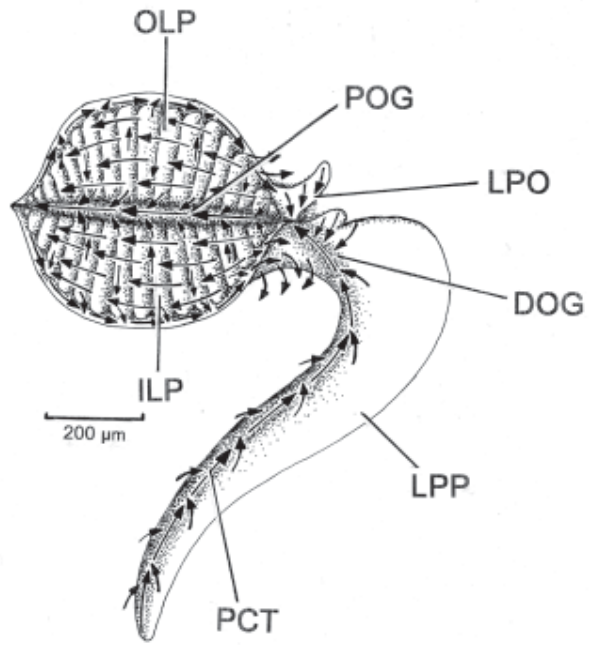

FIGURE 10 Nucula pusilla. Detail of the labial palp - palp proboscide junction showing the ciliary currents. (For abbreviations see Appendix).

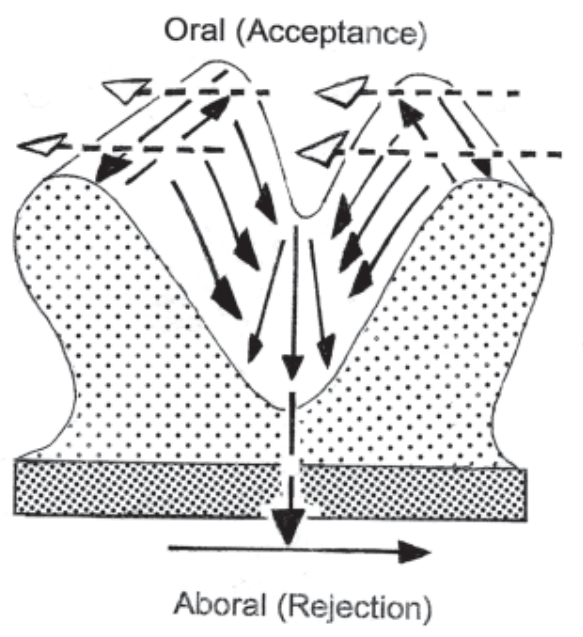

FIGURE 11 Nucula pusilla. Ciliary currents of two ridges and an intervening gutter of the labial palps.

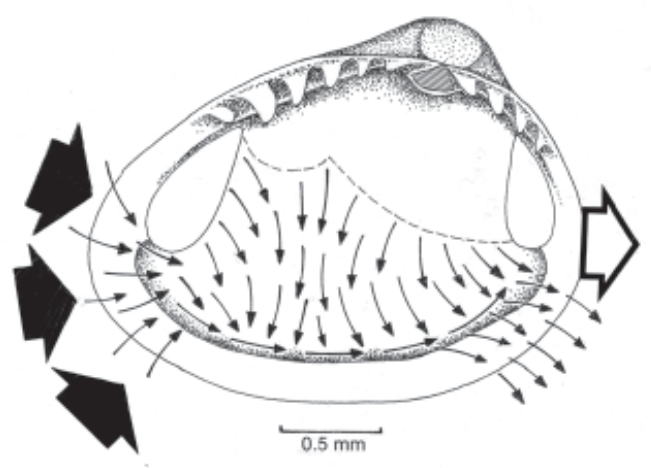

FIGURE 12 Nucula pusilla. Ciliary currents of the left mantle lobe. 


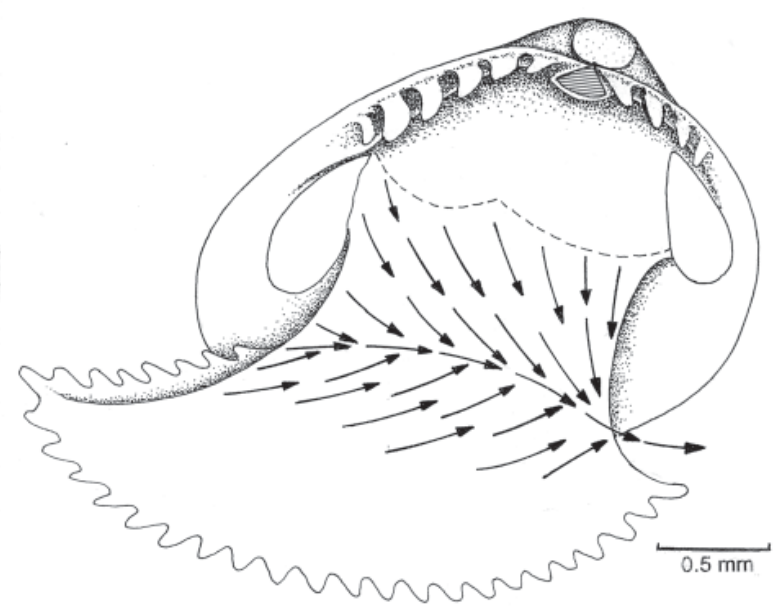

FIGURE 13 Nucula pusilla. Ciliary currents of the visceral mass after removal of the right mantle lobe, ctenidia and palps.

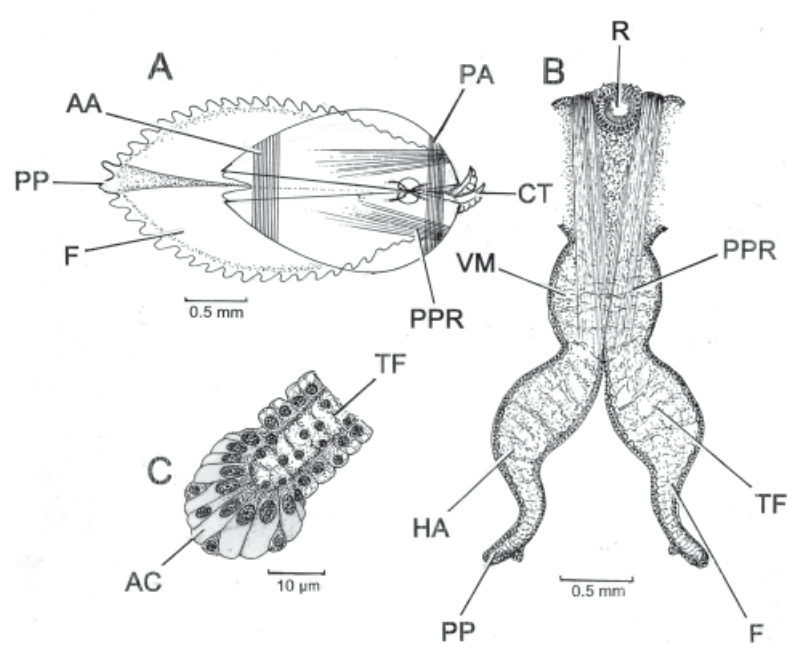

FIGURE 14 Nucula pusilla. A. Extended foot as seen from above. B. Transverse section through the foot with C., a detail of the tip of one of the pedal projections. (For abbreviations see Appendix).

In summary, material rejected for ingestion by the outer labial palps of Nucula pusilla is collected by the ciliary currents of the mantle (Figure 12). These cilia pass material downwards and in a broadly posterior direction, contributing to a posteriorly directed current at the mantle margin in the groove between the general mantle surface and the inner mantle fold. At the posterior margin of the mantle, all unwanted material is rejected from the mantle cavity.
Similarly, material rejected for ingestion by the inner labial palps of Nucula pusilla is collected by the ciliary currents of the visceral mass (Figure 13). On the dorsal region of the visceral mass, as with the mantle, unwanted material is passed downwards in a general posterior direction. Conversely, on the ventral region at the base of the foot, material is passed upwards and in a broadly posterior direction. This latter material has not been rejected by the inner labial palps but is unwanted material entering the mantle cavity, possibly in the inhalant stream, and has to be removed. Both ciliary areas contribute to a posteriorly directed rejection tract in the mid central region of the visceral mass and any material caught in this stream is rejected from the mantle cavity.

\section{The foot}

When seen from above, the extended and expanded foot of Nucula pusilla (Figure 14A, F) has the shape of a frilled, or stellate, ploughshare, that is, it is steeply sharp at the front (anteriorly) but flared outwards towards the rear (posteriorly). The marginal frill of the foot comprises pedal papillae (PP), the shell sits atop the foot to the rear and when the adductor muscles, anteriorly (AA) and posteriorly (PA) relax, the foot can be extended and, as described above (Figure 3), be withdrawn by contraction of the relaxed and extended posterior pedal retractor muscle (PPR).

In transverse section (Figure 14B), the foot of Nucula pusilla (F) is laterally bilobed, so when contracted, the left and right sides fold downwards so it can be withdrawn into the mantle cavity between the shell valves. The paired posterior pedal retractors (PPR) extend into the visceral mass (VM) and between them, dorsally, is the rectum ( $\mathrm{R})$. The foot is abyssate (at least in the adult) and contains an extensive haemocoel (HA), which is expanded when blood is pumped into it. Numerous transverse muscle fibres (TF) that link opposing epithelia prevent overfilling.

As noted above, the left and right margins of the foot are frilled by stumpy pedal papillae (PP). In transverse section (Figure 14C) the tips of these pedal projections are swollen terminally, and each swelling has an epithelium that comprises apical cells (AC) interspersed by distal darkly staining, triangular cells. As with the foot, the epithelia of each papilla are interlinked by transverse muscle fibres (TF).

Although no nerve cells have been identified, the pedal papillae of Nucula pusilla have the general appearance of being sensory. The foot has the same frilled structure seen in Solemya parkinsoni illustrated in its inflated form by Owen (1961, figure 2D). The foot of $S$. velesiana has the same structure and Taylor et al. (2008, figure 12) have shown that the swollen apical region of the pedal papillae of this species, as in N. pusilla, are sensory and possess numerous, possibly chemo- or mechano-receptive pores scattered over their surfaces. 


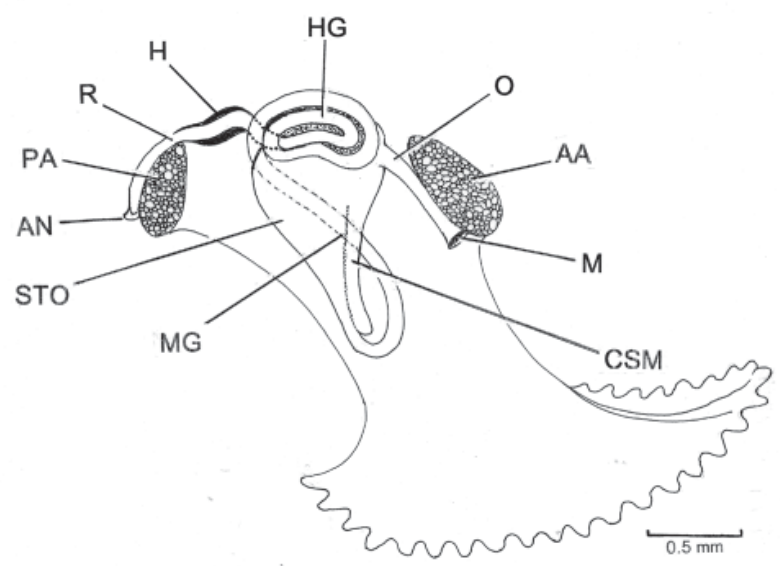

FIGURE 15 Nucula pusilla. Course of the intestine in the visceral mass, as seen from the right side. (For abbreviations see Appendix).

\section{The organs of the visceral mass}

No attempt has been made to identify the structure of the stomach of Nucula pusilla due to its minuteness. The nuculid stomach has been previously described by Graham (1949; N. hanleyi), Purchon (1956; N. nucleus) and Owen $(1956 ; N$. sulcata) in great detail. The long and convoluted intestine in the visceral mass of $N$. pusilla is illustrated from the right side in Figure 15. The mouth (M) is located on the postero-ventral base of the anterior adductor muscle (AA) and leads into a long oesophagus (O), which opens into the stomach (ST) anteriorly. The conjoined style sac and midgut (CSM) arise from the ventral base of the stomach and extend downwards into the visceral mass and, ventrally, the midgut $(\mathrm{MG})$ separates from the style sac with an upward course, Adjacent to the dorsal region of the stomach, the midgut coils a number of times on the right side of the visceral mass and eventually becomes the hindgut (HG) which passes posteriorly and becomes the rectum $(\mathrm{R})$, penetrating the ventricle of the heart (H) and looping over the posterior adductor (PA) to terminate on the posterior face of this muscle in an anus (A). A number of studies have been undertaken on the convoluted route of the intestine in other representatives of the Nuculidae, e.g. N. proxima Say, 1822 and $N$. annulata Hampson, 1971 by Hampson (1971, figures 2(a) and (b)), respectively, and for N. proxima Say, 1822 and N. cancellata Meek and Hayden, 1856 by Allen (1978, figures 10(a) and 10(b)) respectively. All reveal an underlying similarity, the midgut and hindgut are always convolute and loop on the right side of the visceral mass and reflect the common deposit feeding mode of life and source of nutrition. In contrast, Pelseneer (1911) reported, that in $N$. (=Leionucula) cumingi (Hinds, 1843), the rectum passes underneath the heart, not through it as in N. pusilla.

Arising from the postero-ventral end of the stomachs of all nuculids (Hampson 1971) is a plump style sac that typically contains a protostyle. Histological transverse sections through the style sac of Nucula pusilla shows the midgut arises from the ventral terminus of the style sac and returns dorsally alongside it (Figure 16). Morton (1969) described the structure of the style sac of the lamellibranch Dreissena polymorpha (Pallas, 1771) and showed it to comprise four epithelial types, A, B, C and D identified by Kato and Kubomura (1954). In $N$. pusilla, the major epithelial cells are type A (A) and are $\sim 15 \mu \mathrm{m}$ tall with long $(15 \mu \mathrm{m})$ cilia. Type B cells (B) are taller $(\sim 30 \mu \mathrm{m})$ and have similar sized cilia to the A type cells. Between these two cell types occur types C and D cells $(\sim 5 \mu \mathrm{m}$ tall $)$ as in D. polymorpha, but these cannot be differentiated in N. pusilla and there is, instead, a simple ciliated gutter (C/D). The contained style (S) is a simple amorphous mass of mucus and ingested debris. The midgut situated below the style sac is a simple ciliated tube (Figure 16).

Originally, Owen (1956) considered that Nucula sulcata only digested ingested material extracellularly but subsequently demonstrated that digestion was both extra- and intracellular (Owen 1973), these being the functions of the style and digestive diverticula respectively. The function of the style is enhanced by its rotation against the gastric cuticle or shield that lines the left side of the stomach of $N$. sulcata (and N. pusilla [Figure 19, GS]) and which is enzymatically active (Halton and Owen 1968).

\section{Comparison with Nucula sulcata}

The style sac and midgut of Nucula sulcata are illustrated in transverse section for comparison (Figure 17). The style sac of N. sulcata has the same A (A) and B (B) type cells comprising $>90 \%$ of the epithelium. In this species, however, the $C(C)$ and D (D) type cells are clearly differentiated with the former abutting the $\mathrm{B}$ type epithelium (B) and comprising short $(\sim 8 \mu \mathrm{m})$ ciliated cells and the latter abutting the A type cells (A) and comprising a longer row of taller $(\sim 12 \mu \mathrm{m})$ ciliated cells. There is also a simple amorphous style present with the style sac, unlike in $N$. pusilla, enclosed in a thick collagen sheath (CS), within which there is a definable blood vessel (BV). Unlike N. pusilla, the ciliated midgut epithelium of $N$. sulcata is pleated (PEP) and, as with the style sac, the midgut is surrounded by a collagen sheath (CS) with a distinctive blood vessel (BV) (Figure 17).

The visceral mass of both Nucula sulcata and $N$. pusilla contain paired statocysts and are of the same structure (Figure 18). In transverse section, the statocysts are located above the paired pedal ganglia (PED). Each statocyst is $\sim 25 \mu \mathrm{m}$ in diameter, comprises a low, sparsely ciliated, epithelium, and within each statocyst is a cluster of tiny $(<1-2 \mu \mathrm{m})$ crystalline statoconia. Morton (1985) described the variation in statocyst structure in representatives of the bivalve subclass Anomalodesmata. The statocysts of N. pusilla conform to type $\mathrm{B}_{2}$ (Morton 1985) as they are situated above and in contact with the pedal ganglia, but there is no distinguishable statolith amongst the array of statoconia. 


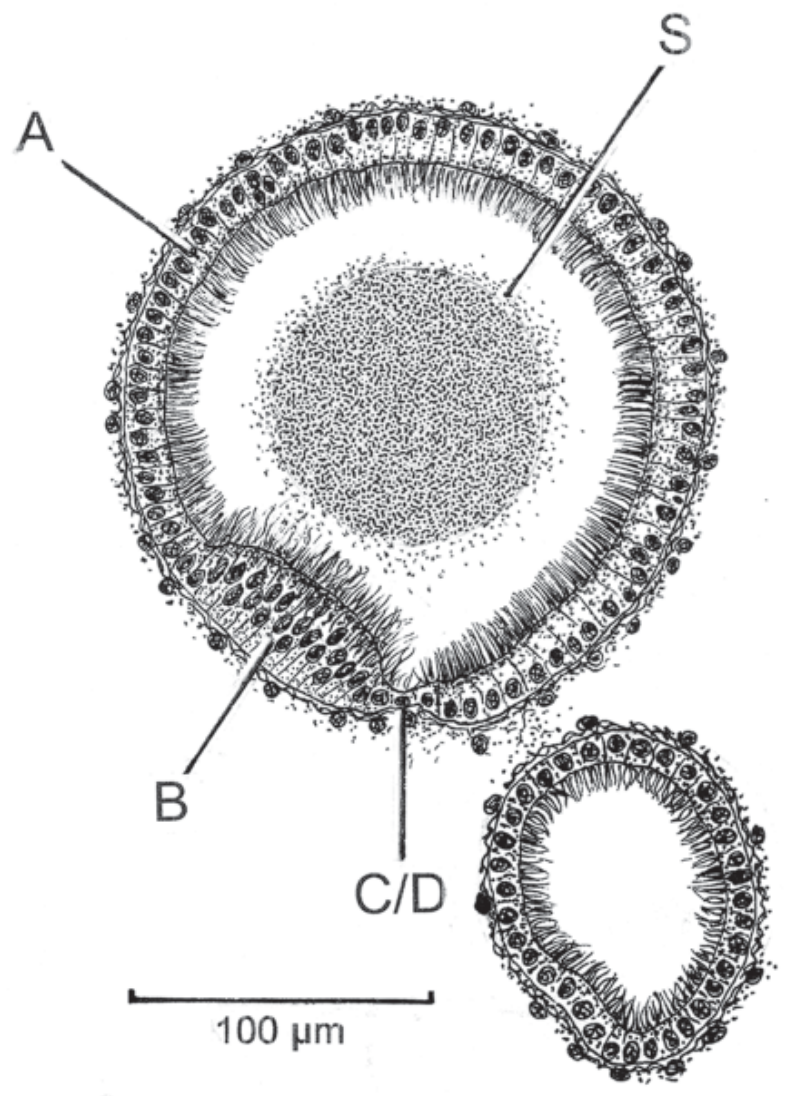

FIGURE 16 Nucula pusilla. Transverse sections through the style sac and midgut. (For abbreviations see Appendix).

\section{REPRODUCTION}

A transverse section through the posterior region of the body of Nucula pusilla (Figure 19), beneath the ligament (L) reveals the disposition of the ovaries and their size. Most of the capacity of the visceral mass, especially dorsally, is filled with large ova (OV) $50 \mu \mathrm{m}$ in diameter each with a large $(15 \mu \mathrm{m})$ nucleus $(\mathrm{N})$. More ventrally is the stomach (ST) with a gastric shield (GS) located on its left side and beneath this is the midgut (MG). The right side of the visceral mass contains further coils of the mid- and hindgut (HG) while the left side contains most of the digestive diverticulae (DD). The hypobranchial glands (HG) are located in the mantle tissues, both left and right and extend (not shown) into the ctenidial axes.

A section through the hypobranchial gland of Nucula pusilla shows it comprises two cell types as described for N. nucleus by Morton (1977) in both its secretory and non-secretory phases. The majority of the gland (Figure 20) comprises large secretory cells (SC) some up to 50 $\mu \mathrm{m}$ tall, interspersed apically by inverted flask-shaped ciliated cells (CC). In the connective tissues in between the internal and external mantle epithelia, are purple staining subepithelial secretory cells (SEC).

The individuals of Nucula pusilla herein reported

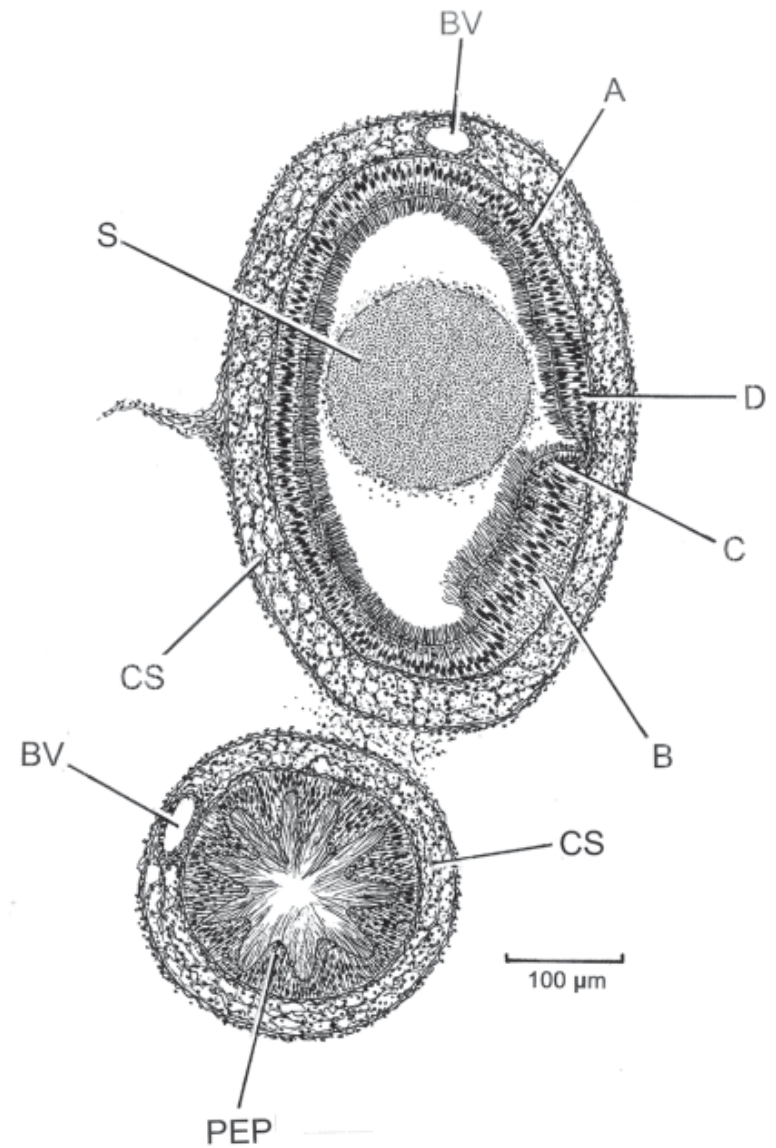

FIGURE 17 Nucula sulcata. Transverse sections through the style sac and midgut. (For abbreviations see Appendix).

were not brooding eggs. Bergmans (1978) recorded that an individual of this species with a $2.90 \mathrm{~mm}$ shell length contained 22 embryos with shell lengths of $\sim 0.45 \mathrm{~mm}$. A second individual of $2.92 \mathrm{~mm}$ shell length contained 26 embryos with shell lengths of between $0.41-0.45 \mathrm{~mm}$. Bergmans (1978) concluded that the embryos of these two individuals were about to begin an independent existence. In this case, the individuals of $N$. pusilla of between $0.8 \mathrm{~mm}$ and $1.6 \mathrm{~mm}$ shell reported in this study represent a recently released cohort, whereas the individuals of between $2.0 \mathrm{~mm}$ and $2.8 \mathrm{~mm}$ shell length represent a cohort from the previous breeding season.

\section{DISCUSSION}

Allen (1978) showed that in the deep sea (depths of between $\sim 100-3,200$ metres) protobranchs might account for more than $70 \%$ of the bivalve species present in a sample and comprise more than $95 \%$ of the total number of bivalves present. This is in contrast to more shallow shelf waters where the protobranchs are less common, accounting for between 10 to $15 \%$ of the numbers of bivalve species present and considerably fewer of the total numbers of individuals. On both the slope and the shelf, representatives of the Nuculidae are the most commonly encountered protobranchs, but not 


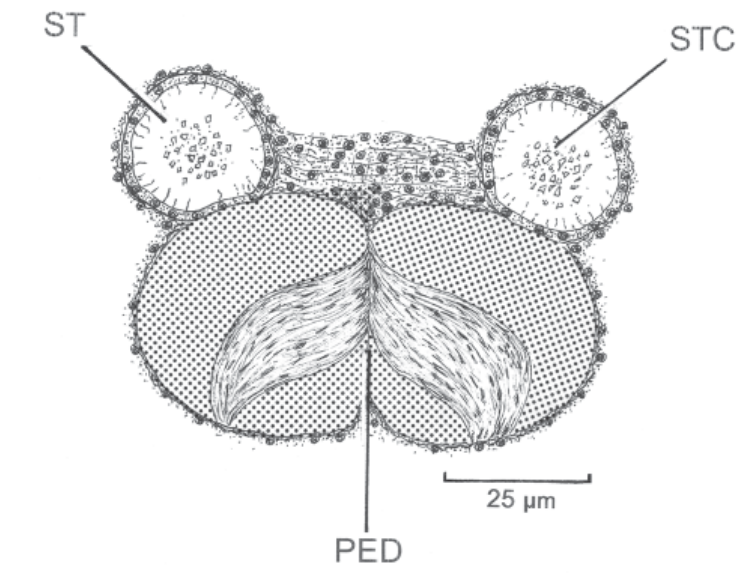

FIGURE 18 Nucula pusilla. Transverse section through the paired statocysts. (For abbreviations see Appendix).

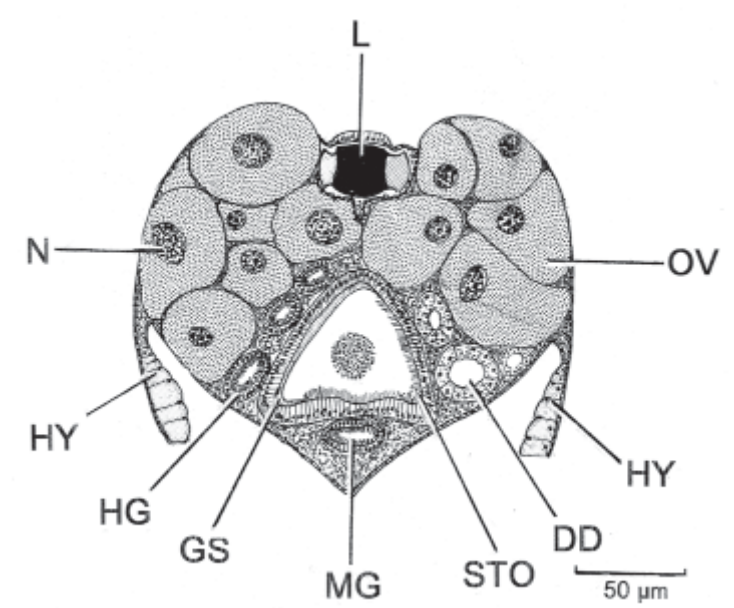

FIGURE 19 Nucula pusilla. Transverse section through the posterior region of the body showing the disposition of the ovaries. (For abbreviations see Appendix).

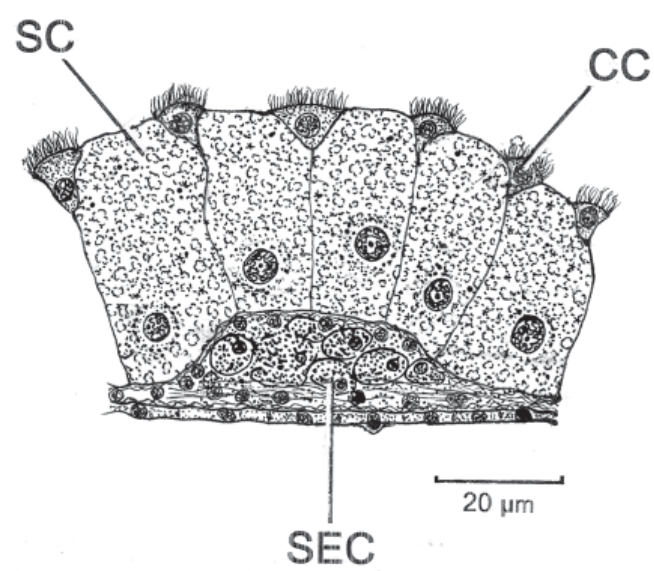

FIGURE 20 Nucula pusilla. A section through the postero-dorsal region of the mantle showing the hypobranchial gland. (For abbreviations see Appendix). in the abyss where they are replaced by representatives of the Nuculanidae.

Nucula pusilla belongs to Allen's slope and shelf category (depths $<\sim 100-3,200$ metres) and can be defined as a shallow shelf, southern temperate, mobile, infaunal, deposit feeding (but see below) bivalve. In general, nuculids occupy a wide range of subtidal sediment types but $N$. pusilla seems to be confined to well sorted inshore coarse sands. This study has elaborated aspects of this species biology and functional morphology - the latter a reflection of its lifestyle and the means by which it is facilitated. In most respects, $N$. pusilla is a typical nuculid and thus, as Yonge (1939) believed, representative of the primitive, or ancestral condition in the Bivalvia. Occurring almost worldwide and at most depths today, the many modern representatives of the Nuculidae are highly successful and specialised animals. Therefore, it is possible to suggest that modern nuculids are a window into the ancestry of the Bivalvia and not necessarily 'primitive'. However, the situation in $N$. pusilla is complicated by its small size.

Runnegar (1978) described how the Early and Middle Cambrian rostroconchs, generally considered to be the ancestors of the first bivalve Fordilla, were small - less than $8 \mathrm{~mm}$ in length. The first described species, $F$. troyensis Barrande, 1881 (Pojeta et al. 1973) was only a few millimetres long as were the earliest Cambrian bivalves contained within genera of Pojetaia Jell, 1980, Tuarangia MacKinnon, 1982, Camya Hinz-Schallreuter, 1995 and Arhouriella Geyer and Streng, 1998 (Elicki and Gürsu 2009). Despite the high numbers of fossil bivalve species now identified, virtually nothing is known about their mode of life, although the laterally compressed shell form suggests a shallow burrowing, endobenthic habit. Thus species of Nucula appear to be a model upon which to base interpretations of the early bivalve lifestyle. This study identifies anatomical features of principal interest to this hypothesis and examines whether these result from a miniature body form or might be representative of a primitive bivalve condition.

One consequence of miniaturisation might be the loss of musculature. Nucula sulcata (Haszprunar 1985) possesses both anterior and posterior pedal retractor muscles (and a posterior pedal protractor muscle), but the former has been lost in N. pusilla. The bivalve superfamily Galeommatoidea also have miniaturised representatives which are often commensal or parasitic, and have loss of musculature. Species of sympatric Australian Scintillona, e.g. S. cryptozoica (Hedley, 1917) and S. daviei Morton, 2008 have both lost their pedal retractor muscles (Morton 2008). Similarly, the monospecific Chlamydoconchoidea (probably Galeommatoidea), represented by Chlamydoconcha orcutti Dall, 1884 in Californian waters, shows evidence of miniaturisation and the loss and extreme reduction of components of its musculature (Morton 1981). However, in other respects these species follow the typical bivalve 
format suggesting that other features of the anatomy of $N$. pusilla may represent a more primitive condition.

The style sac and its contained structure, the style, is usually referred to as a 'protostyle' (J.E. Morton 1971) in the Protobranchia possibly because of (i) its assumed affinity to a primitive condition and (ii) its simplified unlaminated structure quite distinct from the concentrically ringed 'crystalline' style of 'higher' lamellibranchs. The structures fulfill a similar function, the release of enzymes that initiate extracellular digestion in the stomach, identified for the Nuculidae, for example by Owen (1956), and for the bivalves in general by Morton (1983). Both style types are responsible for the trituration of ingested material in the stomach, with their revolving motion due mainly to the A and B type cells that make up the style sac epithelium. C and D type cells are characteristic of both the lamellibranchs with a style sac that is separate from the midgut e.g. Dreissena polymorpha (Morton 1969) and the protobranchs, e.g. Nucula sulcata. However, the style sac of $N$. pusilla has a much simplified structure with type $\mathrm{C}$ and $\mathrm{D}$ cells unidentifiable. It is possible that this may represent a simpler, more primitive condition. Similarly, the midgut of $N$. pusilla is a simple tube unlike the longitudinally pleated structure seen in $N$. sulcata. Finally, the style sac and midgut of $N$. sulcata are surrounded by a thick coat of collagen, whereas those of $N$. pusilla are not. This could suggest that the former species is a true deposit feeder needing to limit amounts taken into the gut, whereas in the latter, less sedimentary material is ingested (see below). Therefore, it would seem that the simpler style sac of $N$. pusilla and the lack of a collagen coat to the intestine might represent a simpler, more primitive ancestral condition (see below).

Graham (1949) studied the stomach of Nucula hanleyi and argued that its structure did not (wholly) suggest primitiveness but was adapted to the extracellular digestion of large amounts of sediment. An analogous situation was described by Purchon (1956; 1959) who found similarities between the stomachs of the Nuculidae and the septibranch representatives of the Anomalodesmata, leading him to suggest (Purchon 1963, page 78) 'that the [specialised] Septibranchia arose directly from a [primitive] protobranchiate ancestor'. Yonge and Morton (1980) dispelled this notion with representatives of the subclass Anomalodesmata having no affinity, save an ancient phylogenetic one (like all modern bivalves) with the Protobranchia. The similarities between the stomachs are principally the result of the ingestion of large particles of food which is living prey in all families of anomalodesmatan 'septibranchs', and surface deposits in most protobranchs. There is thus a commensurate greater importance placed upon extracellular digestion in the stomach of representatives of both phylogenies.

The periostracal groove in the mantle margin of Nucula pusilla is extraordinarily long, reaching almost to the point of the pallial attachment to the shell at the pallial line, compared to $N$. sulcata where it is very short, as it is in the majority of bivalves. The situation in the former is clearly not the result of miniaturisation since it would be of advantage in a small animal, to possess a miniature version of the typical and obviously successful bivalve format. This suggests that it may be representative of a primitive condition.

The Stempel's organ is very simple in Nucula pusilla, but extraordinarily complex in $N$. sulcata (Haszprunar 1985). This would also suggest a more primitive, perhaps basic, condition in N. pusilla with an elaboration of the structure in a larger but perhaps more 'advanced' N. sulcata.

Most studied representatives of the Nuculidae have a lecithotrophic larva, which has a short pelagic life that may consist of a few days (Ockelmann 1965). The most well known species in this respect is Nucula nitida G. B. Sowerby I, 1833 (Thorson 1950) and N. pusilla appears to have a similar reproductive strategy in that its larvae (adults brood 20 individuals in the mantle cavity (Bergmans 1978)) are lecithotrophic and can only have a short pelagic life. In contrast, $N$. delphinodonta Mighels and Adams, 1842 produces a brood sac that is attached to the posterior end of the shell (Drew 1901) and contains between 20-70 eggs, $210 \mu \mathrm{m}$ in diameter, that may be fertilised in the sac. Hypobranchial glands are formed in the dorsal mantle and ctenidial axes about the time $N$. delphinodonta becomes mature, and these appear to supply the secretions from which the brood sac is formed. $N$. pusilla has a large hypobranchial gland but does not produce a brood sac. Intuitively it would seem that the reproductive strategy of $N$. delphinodonta is more advanced and that $N$. pusilla and many congeners, which share this reproductive strategy, are representative of a more primitive ancestral condition.

A consensus view of the four characteristics of Nucula pusilla discussed above is that the species seems more representative of a primitive nuculid condition. Is there any other, possibly conjectural, support for this suggestion? Yonge (1959, p. 211) reported upon the researches of Miss Joan Mortimer on the feeding of post-larval Nucula (species not identified). According to Yonge, Miss Mortimer noted that during early growth and before the development of the palp proboscides, the ctenidia, which develop early and have a functional contact with the labial palps, are the sole means of food collection. This suggests that in its early development this species of Nucula is a ctenidial suspension feeder. With continuing development, the palp proboscides take over the collection of deposits and the ctenidial suspension feeding mode is lost. Yonge concluded that the early appearance of ciliary [ctenidial] feeding may indicate how, by a process of paedomorphosis, the purely ciliary feeding bivalves [the lamellibranch bivalves] came into existence.' Given the importance that Yonge was later to place upon the process of paedomorphosis in the evolution of the heteromyarian (Yonge and Campbell 1968) and ultimately the monomyarian forms in the Bivalvia 
(Yonge 1953), it is surprising that he did not elaborate upon the significance of Miss Mortimer's observations regarding the development of Nucula in any subsequent publication.

In the above context, it is pertinent to note that Drew (1901, page 352) wrote of Nucula delphinodonta: 'The posterior and lateral walls of the stomach [the style sac] ... secrete a mucus-like material that stains deeply, and probably corresponds to the crystalline style. In adults this structure seldom takes the form of a rod, but in embryos a rod is commonly present.' This might be taken as further evidence to suggest that a change in diet from suspension to detritus feeding occurs in this nuculid during ontogeny. If such a change takes place in $N$. pusilla which has evidence of a much more intimate connection between the labial palps, palp proboscides and ctenidia described (above), and also demonstrated for Acila castrensis by Stasek (1961), then a case is emerging for nuculids to be considered to represent a link between the earliest and ancestral (protobranch) and more modern and derived (lamellibranch) bivalves. Through the process of paedomorphosis, resulting in miniaturisation, seen in the earliest bivalves this may represent the means by which the suspension feeding lamellibranchs first evolved, only later to return to a deposit feeding mode of life in, for example, the Tellinoidea (Yonge 1949) and Mactroidea (Morton 2010).

In conclusion, the initial question of this study was to resolve: is the small size of Nucula pusilla the result of either primitive or miniature simplicity? The answer is probably positive to both. As with many (all?) species, form and function result ultimately from ancestry and the evolutionary path arising from natural selection. However, in this study many of the aspects of the morphology and lifestyle of $N$. pusilla, such as the structure of the mantle margin, the structure of Stempel's organ, the simplicity of the intestine and mantle cavity, and brooding of fertilised eggs, suggest a 'primitive', or ancestral nuculid form. On the other hand, the overall body plan of $N$. pusilla suggests simplicity resulting from miniaturisation.

These conclusions, however, raise other interesting questions. Could miniaturisation have resulted in the return to some of the characteristics of earlier life history stages, such as the greater intimacy expressed in $N$. pusilla between the ctenidia, palp proboscides and labial palps, suggesting (as proposed by Stasek 1961) the collection of suspended as well as deposited food resources? If this is true, and taking into account the observations of Yonge (1959) and Drew (1901) discussed above, does this represent the means, through paedomorphosis in a nuculid ancestor, by which the 'higher' lamellibranch bivalves have so successfully adopted the ctenidial suspension feeding mode of life (albeit with a return to deposit feeding in a few) and their success in a less circumscribed lifestyle? If this is the case, then the tiny $N$. pusilla might illuminate how this has occurred. Interestingly, Ockelmann (1964) suggested that the tiny Turtonia minuta (Fabricius,
1780), which broods fertilised eggs in an egg capsule (as in $N$. delphinodonta) and has been placed in many bivalve superfamilies, including the Galeommatoidea discussed above, might be a neotenous veneroidean. This suggests that through paedomorphosis, the veneroidean T. minuta has reverted to a more 'spat-like' post larval condition with anatomical modifications, including to the mantle, and the adoption of larval brooding. An analogy with the Nuculoida and N. pusilla is inescapable, although certainly coincidental.

\section{ACKNOWLEDGEMENTS}

I am grateful to Dr F.E. Wells, formerly of the Western Australian Museum (WAM) for organizing the Fifth International Marine Biological Workshop convened on Rottnest Island in January 1991 where this research was undertaken, and Diana Jones also of WAM, for kind hospitality and friendship. George Kendrick and Shirley Slack-Smith provided information on Nucula pusilla in the fossil and Recent collections of WAM, respectively, and Dr J.D. Taylor (The Natural History Museum, London) kindly took the SEM pictures. I am finally grateful to two reviewers of the first draft of the manuscript of this paper for their constructive comments and criticisms which helped to improve the final version.

\section{REFERENCES}

Allen, J.A. (1952). Observations on Nucula turgida Marshall and $N$. moorei Winkworth. Journal of the Marine Biological Association of the United Kingdom 31: 515-517.

Allen, J.A. (1954). A comparative study of the British species of Nucula and Nuculana. Journal of the Marine Biological Association of the United Kingdom 33: 457-472.

Allen, J.A. (1978). Evolution of the deep sea protobranch bivalves. Philosophical Transactions of the Royal Society of London, Series B 284: 387-401.

Angas, G.F. (1877). Description of one genus and twentyfive species of marine shells from New South Wales. Proceedings of the Zoological Society of London 1877 : 171-177.

Atkins, D. (1937). On the ciliary mechanisms and interrelationships of lamellibranchs. Part I: New observations on sorting mechanisms. Quarterly Journal of Microscopical Science : 181-308.

Atkins, D. (1938). On the ciliary mechanisms and interrelationships of lamellibranchs. Part VII. Latero-frontal cilia of the gill filaments and their phylogenetic value. Quarterly Journal of Microscopical Science : 346-430.

Bergmans, W. (1978). Taxonomic revision of Recent Australian Nuculidae (Mollusca: Bivalvia) except Ennucula Iredale, 1931. Records of the Australian Museum 31(17): 673-736.

Drew, G.A. (1899). Some observations on the habits, anatomy and embryology of members of the Protobranchia. Anatomischer Anzeiger 15(24): 493-519.

Drew, G.A. (1901). The life-history of Nucula delphinodonta (Mighels). Quarterly Journal of Microscopical Science 44: 313-391.

Elicki, O. and Gürsu, S. (2009). First record of Pojetaia runnegari Jell, 1980 and Fordilla Barrande, 1881 from the 
Middle East (Taurus Mountains, Turkey) and critical review of Cambrian bivalves. Paläontologische Zeitschrift 83: 267-291.

Forbes, E. and Hanley, S. (1853). A history of British Mollusca and their shells. Vol. 2. John van Voorst: London:

Glover, E.A. and Taylor, J.D. 1999. Diversity and distribution of subtidal macromolluscs around Rottnest Island, Western Australia. In D.I.Walker and F.E.Wells (eds), The seagrass flora and fauna of Rottnest Island, Western Australia. pp. 101-119. Western Australian Museum Press: Perth.

Graham. A. (1949). The molluscan stomach. Transactions of the Royal Society of Edinburgh 61: 737-778.

Halton, D.W. and Owen, G. (1968). The fine structure and histochemistry of the gastric cuticle of the protobranchiate bivalve, Nucula sulcata Bronn. Proceedings of the Malacological Society of London 38: 71-81.

Hampson, G.R. (1971). A species pair of the genus Nucula (Bivalvia) from the eastern coast of the United States. Proceedings of the Malacological Society of London 39: 333-342.

Haszprunar, G. (1985). On the anatomy and fine structure of a peculiar sense organ in Nucula (Bivalvia: Protobranchia). The Veliger 28(1): 52-62.

Heath, H. (1937). The anatomy of some protobranch mollusks. Mémoires du Musée royale d'histoire naturelle de Belgique 10: $1-26$.

Huber, M. (2010). Compendium of bivalves. A full-color guide to 3,300 of the world's marine bivalves. A status on Bivalvia after 250 years of research. Conchbooks: Hackenheim.

Kato, K. and Kubomura, K. (1954). On the origins of the crystalline style of lamellibranchs. Scientific Reports, Saitama University B3: 135-152.

Keen, A.M. (1969). Family Nuculidae Gray, 1824. In R.C.Moore (ed), Treatise on Invertebrate Palaeontology, (N), Mollusca 6 (1 of 3). pp. N230-N231. Geological Society of America and University of Kansas Press: Lawrence, Kansas.

Lamprell K. and Healy J. (1998). Bivalves of Australia. Vol. 2. Backhuys Publishers: Leiden.

Macleod, C. and Forbes, S. (eds). (2004). Guide to the assessment of sediment condition at marine finfish farms in Tasmania. Tasmanian Aquaculture and Fisheries Institute, University of Tasmania.

Mikkelsen, P.M. and Bieler, R. (2008). Family Nuculidae - nut clams. pp. 24-27. In Seashells in Southern Florida: living marine mollusks of the Florida Keys and adjacent regions. Bivalves. Princeton University Press: Princeton, New Jersey.

Moore, D.R. (1977). Small species of Nuculidae (Bivalvia) from the tropical western Atlantic. The Nautilus 91(4): 119-128.

Morton, B. (1969). Studies on the biology of Dreissena polymorpha Pall. (I). General anatomy and morphology. Proceedings of the Malacological Society of London 38: 301-321.

Morton, B. (1977). The hypobranchial gland in the Bivalvia. Canadian Journal of Zoology 55: 1225-1234.

Morton, B. (1981). The biology and functional morphology of Chlamydoconcha orcutti Dall with a discussion on the taxonomic status of the Chlamydoconchacea (Mollusca: Bivalvia). Journal of Zoology, London 195: 81-122.

Morton, B. (1983). Feeding and digestion in the Bivalvia. In K.M. Wilbur and A.S.M. Saleuddin (eds), The Mollusca. Vol. 5, Part 2, Physiology. pp. 65-147. Academic Press: New York.
Morton, B. (1985). Statocyst structure in the Anomalodesmata (Bivalvia). Journal of Zoology, London 206: 23-34.

Morton, B. (2008). The biology of sympatric species of Scintillona (Bivalvia: Galeommatoidea) commensal with Pilumnopeus serratifrons (Crustacea: Decapoda) in Moreton Bay, Queensland, with a description of a new species. Memoirs of the Queensland Museum - Nature 54: 323-338.

Morton, B. (2010). Form and functional morphology of Raetellops pulchella (Bivalvia: Mactridae): an example of convergent evolution with anomalodesmatans. Invertebrate Biology 129: 241-251.

Morton, B. and Peharda, M. (2008). The biology and functional morphology of Arca noae (Bivalvia: Arcidae) from the Adriatic Sea, Croatia, with a discussion on the evolution of the bivalve mantle margin. Acta Zoologica (Stockholm) 89: 19-28.

Morton, J.E. (1971). Molluscs. Hutchinson and Co.: London.

Ockelmann, K.W. (1964). Turtonia minuta (Fabricius), a neotenous veneracean bivalve. Ophelia 1: 121-146.

Ockelmann, K.W. (1965). Developmental types in marine bivalves and their distribution along the Atlantic coast of Europe. Proceedings of the First European Malacological Congress, London 1962. pp. 25-35.

Orton, J.H. (1912). Mode of feeding of Crepidula, and in Gastropoda and Lamellibranchs. Journal of the Marine Biological Association of the United Kingdom 9 (New Series, 1910-1913): 444-478.

Owen, G. (1956). Observations on the stomach and digestive diverticula of the Lamellibranchia. II. The Nuculidae. Quarterly Journal of Microscopical Science 97: 541-567.

Owen, G. (1961). A note on the habits and nutrition of Solemya parkinsoni (Protobranchia: Bivalvia). Quarterly Journal of Microscopical Science 102: 15-21.

Owen, G. (1973). The fine structure and histochemistry of the digestive diverticula of the protobranchiate bivalve Nucula sulcata. Proceedings of the Royal Society of London. Series B 183: 249-264.

Pelseneer, P. (1891). Contribution á l'étude des lamellibranches. Archives of Biological Sciences, Belgrade 11: 147-312.

Pelseneer, P. (1911). Les lamellibranches de l'expedition du Siboga. Partie Anatomique. Siboga-Expeditie LIIIa: 1-125 + plates I-XXVI.

Pojeta, J.P., Jr., Runnegar, B. and Křiž, J. (1973). Fordilla troyensis: the oldest known pelecypod. Science 180: 866-868.

Purchon, R.D. (1956). The stomach in the Protobranchia and Septibranchia. Proceedings of the Zoological Society of London 127: 511-525.

Purchon, R.D. (1959). Phylogenetic classification of the Lamellibranchia, with special reference to the Protobranchia. Proceedings of the Malacological Society of London 33: 224-230.

Purchon, R.D. (1963). Phylogenetic classification of the Bivalvia, with special reference to the Septibranchia. Proceedings of the Malacological Society of London 35: 251-271.

Reid, R.G.B. and Reid, A.M. (1974). The carnivorous habit of members of the septibranch genus Cuspidaria (Mollusca: Bivalvia). Sarsia 56: 47-56.

Runnegar, B. (1978). Origin and evolution of the Class Rostroconchia. Philosophical Transactions of the Royal Society of London, Series B 284: 319-333. 
Sanders, H.L. and Allen, J.A. 1973. Studies on deep-sea Protobranchia (Bivalvia); prologue and the Pristoglomidae. Bulletin of the Museum of Comparative Zoology 145(5): 237-262.

Stasek, C.R. (1961). The ciliation and function of the labial palps of Acila castrensis (Protobranchia; Nuculidae). Proceedings of the Zoological Society of London 137: 511-538.

Stasek, C.R. (1963). Synopsis and discussion of the association of ctenidia and labial palps in the bivalved Mollusca. The Veliger 6: 91-97.

Stasek, C.R. (1965). Feeding and particle-sorting in Yoldia ensifera (Bivalvia: Protobranchia), with notes on other nuculanids. Malacologia 2(3): 349-366.

Taylor, J.D, Kennedy, W.J. and Hall, A. (1969). The shell structure and mineralogy of the Bivalvia. Introduction: Nuculacae-Trigonaceae. Bulletin of the British Museum, Natural History (Zoology), Supplement 3: 1-215.

Taylor, J.D., Glover, E.A. and Williams, S.T. (2008). Ancient chemosynthetic bivalves: systematics of Solemyidae from eastern and southern Australia (Mollusca: Bivalvia). Memoirs of the Queensland Museum - Nature 54: 75-104.

Tebble N. (1966). British bivalve seashells. Trustees of the British Museum (Natural History): London.

Thorson, G. (1950). Reproductive and larval ecology of marine bottom invertebrates. Biological Reviews 25(1): 1-45.

Verrill, A.E. and Bush, H.J. (1897). Revision of the genera of Ledidae and Nuculidae of the Atlantic coast of the United States. American Journal of Science 3: 51-63.

Verrill, A.E. and Bush, H.J. (1898). Revision of the deep-water Mollusca of the Atlantic coast of North America, with descriptions of new genera and species. Part I - Bivalvia. Proceedings of the United States National Museum 20: 775-901.

Wells, F.E. and Bryce, C.W. (1985). Seashells of Western Australia. Western Australian Museum: Perth.

Yonge, C.M. (1939). The protobranchiate Mollusca; a functional interpretation of their structure and evolution. Philosophical Transactions of the Royal Society of London, Series B 230: 79-147.

Yonge C.M. (1949). On the structure and adaptations of the Tellinacea, deposit feeding Eulamellibranchia. Philosophical Transactions of the Royal Society of London, Series B 234: 29-76.

Yonge, C.M. (1953). The monomyarian condition in the Lamellibranchia. Transactions of the Royal Society of Edinburgh 62: 443-478.

Yonge, C.M. (1959). The status of the Protobranchia in the bivalve Mollusca. Proceedings of the Malacological Society of London 33: 210-214.

Yonge, C.M. and Campbell, J.I. (1968). On the heteromyarian condition in the Bivalvia with special reference to Dreissena polymorpha and certain Mytilacea. Transactions of the Royal Society of Edinburgh 68: 21-43.

Yonge, C.M. and Morton, B. (1980). Ligament and lithodesma in the Pandoracea and Poromyacea with a discussion on evolutionary history in the Anomalodesmata (Mollusca: Bivalvia). Journal of Zoology, London 191: 263-292.

MANUSCRIPT RECEIVED 11 JANUARY 2012; ACCEPTED 3 OCTOBER 2012. 
APPENDIX Abbreviations used in the figures.

\begin{tabular}{|c|c|c|c|}
\hline A & A cell epithelium of the style sac & $\mathrm{N}$ & Nucleus \\
\hline $\mathrm{AA}$ & Anterior adductor muscle or scar & $\mathrm{O}$ & Oesophagus \\
\hline AN & Anus & OD & Outer demibranch \\
\hline $\mathrm{AC}$ & Apical cells & OLP & Outer labial palp \\
\hline B & B cell epithelium of the style sac & OMF & Outer mantle fold \\
\hline BV & Blood vessel & $\mathrm{OV}$ & Ovum \\
\hline $\mathrm{C}$ & $\mathrm{C}$ cell epithelium of the style sac & OVA & Ovary \\
\hline $\mathrm{CC}$ & Ciliated cell & PA & Posterior adductor muscle or scar \\
\hline $\mathrm{CS}$ & Collagen sheath & PCT & Palp proboscide collection tract \\
\hline CSM & Conjoined style sac and midgut & PE & Periostracum \\
\hline CT & Ctenidia & PED & Pedal ganglia \\
\hline $\mathrm{D}$ & D cell epithelium of the style sac & PEG & Periostracal groove \\
\hline DD & Digestive diverticula & PEP & Pleated epithelium \\
\hline DOG & Distal oral groove & PL & Pallial line \\
\hline $\mathrm{F}$ & Foot & $\mathrm{PN}$ & Pallial nerve \\
\hline GS & Gastric shield & POG & Proximal oral groove \\
\hline $\mathrm{H}$ & Heart & PP & Pedal papillae \\
\hline HA & Haemocoel & PPR & Posterior pedal retractor muscle or scar \\
\hline HG & Hindgut & PRM & Pallial retractor muscle \\
\hline HY & Hypobranchial gland & $\mathrm{R}$ & Rectum \\
\hline ID & Inner demibranch & RPP & Right palp proboscide \\
\hline ILP & Inner labial palp & $\mathrm{S}$ & Style \\
\hline IMF & Inner mantle fold & SEC & Subepithelial secretory cell \\
\hline $\mathrm{L}$ & Ligament & $\mathrm{SC}$ & Secretory cell \\
\hline LPO & Labial palp pouch & SO & Stempel's organ \\
\hline LPP & Left palp proboscides & ST & Statocyst \\
\hline LT & Larval hinge tooth & STC & Statoconia \\
\hline M & Mouth & STO & Stomach \\
\hline MG & Midgut & $\mathrm{TF}$ & Transverse muscle fibres \\
\hline MMF & Middle mantle fold & VM & Visceral mass \\
\hline
\end{tabular}

